\title{
Concanavalin A electrochemical sensor based on the surface blocking principle at an ion-selective polymeric membrane
}

\author{
Marcin Pawlak • Günter Mistlberger • Eric Bakker
}

Received: 10 March 2014 / Accepted: 9 June 2014 / Published online: 24 June 2014

(C) Springer-Verlag Wien 2014

\begin{abstract}
We report on a new electrochemical sensor for Concanavalin A. It is based on blocking the surface of plasticized PVC membranes that were covalently modified with Dmannose using click chemistry. The interaction of D-mannose with Concanavalin A on the surface perturbs the flux of a marker ion for which the ion-selective membrane is responsive, and this results in a change in the electrochemical signal. The sensor was characterized using a variety of electrochemical protocols, and results were confirmed by quartz crystal microbalance experiments. The lowest limit of detection $\left(10 \mu \mathrm{g} \mathrm{mL}^{-1}\right)$ was obtained using a membrane containing a cation exchanger and tetrabutylammonium ion as the marker ion.
\end{abstract}

Keywords Biosensor · Concanavalin A · Click chemistry · Ion selective electrodes $\cdot$ Chronopotentiometry

\section{Introduction}

Carbohydrate recognizing proteins play an important role in biology. One class of such proteins, the lectins, are crucial in cellular interactions [1]. Both carbohydrates and lectins are

\footnotetext{
M. Pawlak · G. Mistlberger · E. Bakker

Department of Inorganic and Analytical Chemistry, University of

Geneva, Quai E.-Ansermet 30, 1211 Geneva, Switzerland

G. Mistlberger

Department of Analytical and Food Chemistry, Graz University of

Technology, Stremayrgasse 9, 8010 Graz, Austria

E. Bakker $(\bowtie)$

Department of Inorganic and Analytical Chemistry, Sciences II, Université de Genève, Quai Ernest-Ansermet 30, CH-1211 Genève, Switzerland

e-mail: eric.bakker@unige.ch
}

commonly found on cell surfaces and thanks to the high selectivity of their interactions they act as a cell recognition tool in processes such as infection, fertilization or cancer metastasis $[2,3]$. Other lectins are thought to have a function in cell adhesion [4] or as a plant defensive mechanism [5]. Lectins are found in most classes of organisms from microbes to animals and while their interactions with carbohydrates are fairly weak they are highly selective.

Some lectins are used in blood typing, as ABO blood types are determined by different carbohydrate chains present at the surface of red blood cells. Using lectins selective for a saccharide results in the agglutination of red blood cells of a given type, allowing to distinguish between different blood types [6].

Concanavalin A belongs to the family of plant lectins and is isolated from Canavalia ensiformis (Jack bean). Under acidic conditions it exists in a dimeric form created from two identical subunits. At $\mathrm{pH}$ above 7 tetramers with a molecular mass of $104 \mathrm{kDa}$ are formed. Concanavalin A is selective for Dmannose and it requires calcium ions in order to adopt the proper conformation for carbohydrate binding [7].

Analytical methods most commonly used to probe carbohydrate-concanavalin A interactions include surface plasmon resonance [8-10], fluorescence spectroscopy [11-16] and electrochemical techniques such as voltammetry $[17,18]$ or electrochemical impedance spectroscopy $[19,20]$.

Recently, electrochemical biosensors based on the surface blocking principle have drawn increased attention [21-28]. In this approach a biorecognition event takes place at or near the surface of a polymeric ion selective membrane and modulates the flux of a marker ion to or from the membrane. This may induce changes in the electrochemical response, which is used as the analytical signal. The use of ion-selective membranes is promising for this purpose since the hydrophobic membrane core coated with a hydrophilic surface is an attractive, yet robust mimic of cell surface architecture [29]. 
In this study, we present a lectin recognition sensor based on the surface blocking principle. The D-Mannose Concanavalin A pair was used as a model system. Mannose was immobilized on the polymeric membrane using a 'click chemistry' method developed in our group [30, 31] and its interactions with Concanavalin A were investigated using a range of electrochemical protocols.

\section{Experimental}

Reagents, materials and equipment

High molecular weight poly (vinyl chloride) (PVC), potassium tetrakis (4-chlorophenyl) borate (KTClPB), tetradodecylammonium tetrakis (4-chlorophenyl) borate (ETH 500), bis (2-ethylhexyl) sebacate (DOS), valinomycin, anhydrous tetrahydrofuran (THF), tetrabutylammonium chloride (TBACl), concanavalin $\mathrm{A}$ together with all reagents and solvents used in the synthesis were purchased from Sigma Aldrich (www.sigmaaldrich.com) and used without further purification. Aqueous solutions were prepared by dissolving the salts in Milli-Q-purified distilled water. Heparinized human blood (added heparin, 1 unit $\mathrm{mL}^{-1}$ ) was obtained from Hôpitaux Universitaires de Genève (HUG). Potentiometric measurements were taken against a double-junction $\mathrm{Ag}$ / $\mathrm{AgCl} / \mathrm{sat}$. KCl/1 M LiOAc reference electrode (Metrohm AG, Switzerland, www.metrohm.ch), using a 16-channel EMF interface (Lawson Laboratories, Inc., Malvern, PA, www.lawsonlabs.com). Electrochemical measurements were performed with an Autolab PGSTAT302N (MULTI 16 module, Metrohm Autolab, Utrecht, The Netherlands, www. ecochemie.nl). Measurements were performed in a onecompartment, three-electrode electrochemical cell. A doublejunction $\mathrm{Ag} / \mathrm{AgCl} / 3 \mathrm{M} \mathrm{KCl} / 1 \mathrm{M} \mathrm{LiOAc}$ reference electrode was used (Metrohm AG, Switzerland). Electrode bodies (Oesch Sensor Technology, www.ostec.ch) were used to mount the polymeric membranes (area $20 \mathrm{~mm}^{2}$ ). A platinum working rod $\left(3.2 \mathrm{~cm}^{2}\right.$ surface area) served as the counter electrode.

\section{Synthesis}

$\mathrm{N}_{3}$ PVC: The substitution reaction of PVC with $\mathrm{NaN}_{3}$ was carried out using $1 \mathrm{~g}$ (16 mmol based on monomeric unit) of PVC and $1.04 \mathrm{~g}(16 \mathrm{mmol})$ of $\mathrm{NaN}_{3}$ in $42 \mathrm{~mL}$ of DMF-water mixture $\left(5: 1\right.$ volume ratio) and heated at $60^{\circ} \mathrm{C}$ under nitrogen for $92 \mathrm{~h}$. When the desired degree of modification was achieved, the reaction mixture was cooled to room temperature; the product was filtered, washed with distilled water and methanol, and subsequently dried under reduced pressure. The azide content was determined using elemental analysis.
3, 6, 9, 12-tetraoxapentadec-14-yn-1-ol [TEG]: To a solution of $10.1 \mathrm{~g}(51.9 \mathrm{mmol})$ tetraetylene glycol in dry THF at $0{ }^{\circ} \mathrm{C}$ under nitrogen atmosphere, $0.85 \mathrm{~g}(21 \mathrm{mmol})$ of $60 \%$ $\mathrm{NaH}$ in oil was carefully added and after $15 \mathrm{~min} 2.37 \mathrm{~mL}$ ( $21 \mathrm{mmol}$ ) of $80 \%$ toluene solution of propargyl bromide was slowly added. The mixture was stirred at $0{ }^{\circ} \mathrm{C}$ for another $3 \mathrm{~h}$, and then allowed to warm to room temperature and left overnight. The solvent was evaporated and the residue extracted with ethyl acetate. After removal of the solvent the product was purified using flash chromatography on silica gel using ethyl acetate as an eluent. Yield $3.4 \mathrm{~g} \mathrm{(15} \mathrm{mmol,} 71 \%)$. ${ }^{1} \mathrm{H}$ NMR $\left(400 \mathrm{MHz} \mathrm{CDCl}_{3}\right): \delta 4.21(\mathrm{~d}, \mathrm{~J}=2.4 \mathrm{~Hz}, 2 \mathrm{H}), 3.76$ $3.67(\mathrm{~m}, 14 \mathrm{H}), 3.61(\mathrm{t}, \mathrm{J}=4.2 \mathrm{~Hz}, 2 \mathrm{H}), 2.67(\mathrm{~s}, 1 \mathrm{H}), 2.44(\mathrm{t}, \mathrm{J}=$ $2.4 \mathrm{~Hz}, 1 \mathrm{H})$.

Pentaacetyl D-mannose: A solution of D-mannose $(5 \mathrm{~g}$, $27.8 \mathrm{mmol}, 1.0$ eq.) in pyridine $(100 \mathrm{~mL})$ was treated with dimethylaminopyridine (DMAP) (339 mg, $2.8 \mathrm{mmol}, 0.1$ eq.) and $(\mathrm{AcO})_{2}(26 \mathrm{~mL}, 278.8 \mathrm{mmol}, 10.0$ eq. $)$. The reaction mixture was stirred for $24 \mathrm{~h}$ at room temperature under an atmosphere of $\mathrm{N}_{2}$. The reaction mixture was diluted with $\mathrm{CH}_{2} \mathrm{Cl}_{2}$, washed twice with $\mathrm{H}_{2} \mathrm{O}$ and the aqueous phases were back-extracted with $\mathrm{CH}_{2} \mathrm{Cl}_{2}$. The combined organic phases were washed with saturated $\mathrm{NaCl}$ solution, dried over $\mathrm{MgSO}_{4}$, filtered and concentrated in vacuum. Product was obtained as a slightly yellow oil (10 g, $92 \%) .{ }^{1} \mathrm{H}$ NMR $\left(400 \mathrm{MHz} \mathrm{CDCl}_{3}\right): \delta$ 6.07 (d, J=1.84 Hz, 1H), $5.34(\mathrm{~m}, 2 \mathrm{H}), 5.25(\mathrm{t}, \mathrm{J}=2.18 \mathrm{~Hz}, 1 \mathrm{H})$, $4.27\left(\mathrm{dd}, \mathrm{J}_{1}=12.40 \mathrm{~Hz}, \mathrm{~J}_{2}=4.88,1 \mathrm{H}\right), 4.07(\mathrm{~m}, 2 \mathrm{H}), 2.17(\mathrm{~s}$, $3 \mathrm{H}), 2.16$ (s, 3H), 2.09 (s, 3H), 2.05 (s, 3H), 2.00 (s, 3H).

Tetraacetyl D-mannose-TEG: A solution of TEG (722 mg, $3.84 \mathrm{mmol}, 1.5 \mathrm{eq}$.$) and the peracetylated D-mannose (1 \mathrm{~g}$, $2.56 \mathrm{mmol}, 1$ eq.) in anhydrous $\mathrm{CH}_{2} \mathrm{Cl}_{2}(10 \mathrm{~mL})$ was cooled to $0{ }^{\circ} \mathrm{C}$ before dropwise addition of $\mathrm{BF}_{3} \cdot \mathrm{Et}_{2} \mathrm{O}(1.82 \mathrm{~g}$, $12.8 \mathrm{mmol}, 5$ eq.). The reaction mixture was stirred at room temperature for $24 \mathrm{~h}$ then poured into saturated aqueous $\mathrm{NaHCO}_{3}(60 \mathrm{~mL})$. The aqueous layer was extracted twice with $\mathrm{CH}_{2} \mathrm{Cl}_{2}$. The organic layers were combined, dried $\left(\mathrm{MgSO}_{4}\right)$, filtered and evaporated under reduced pressure. The oily residue was purified by flash column chromatography on the silica gel (hexane then hexane/EtOAc 3:2) to afford the desired product ( $826 \mathrm{mg}$, yield $57 \%$ ). ${ }^{1} \mathrm{H}$ NMR $(400 \mathrm{MHz}$ $\left.\mathrm{CDCl}_{3}\right): \delta 5.24(\mathrm{~m}, 3 \mathrm{H}), 4.85,(\mathrm{~s}, 1 \mathrm{H}), 4.27\left(\mathrm{dd}, \mathrm{J}_{1}=12.5 \mathrm{~Hz}\right.$, $\left.\mathrm{J}_{2}=5.1 \mathrm{~Hz}, 1 \mathrm{H}\right), 4.18(\mathrm{~m}, 3 \mathrm{H}), 4.06(\mathrm{~m}, 2 \mathrm{H}), 3.80(\mathrm{~m}, 1 \mathrm{H})$, $3.66(\mathrm{~m}, 16 \mathrm{H}), 2.44(\mathrm{t}, \mathrm{J}=2.36 \mathrm{~Hz}, 1 \mathrm{H}), 2.14(\mathrm{~s}, 3 \mathrm{H}), 2.09$ (s, $3 \mathrm{H}), 2.02(\mathrm{~s}, 3 \mathrm{H}), 1.97$ (s, 3H).

D-mannose-TEG: To a solution of tetraacetyl D-mannoseTEG (100 mg, $0.18 \mathrm{mmol})$ in anhydrous methanol $(100 \mathrm{~mL})$ at $0^{\circ} \mathrm{C}$ was added $\mathrm{NaOMe}$ until $\mathrm{pH}$ was 10 . The solution was stirred for $3 \mathrm{~h}$. Dowex cation exchange resin (H form) was added to adjust the $\mathrm{pH}$ to 6 and the mixture was filtered. The filtrate was evaporated to give yellow oil in quantitative yield. ${ }^{1} \mathrm{H}$ NMR (400 MHz CDCl $): \delta 5.40(\mathrm{~m}, 3 \mathrm{H}), 4.95,(\mathrm{~s}, 1 \mathrm{H})$, $4.35\left(\mathrm{dd}, \mathrm{J}_{1}=12 \mathrm{~Hz}, \mathrm{~J}_{2}=5.5 \mathrm{~Hz}, 1 \mathrm{H}\right), 4.20(\mathrm{~m}, 3 \mathrm{H}), 4.10(\mathrm{~m}$, $2 \mathrm{H}), 3.80(\mathrm{~m}, 1 \mathrm{H}), 3.66(\mathrm{~m}, 16 \mathrm{H}), 2.48(\mathrm{t}, \mathrm{J}=2.4 \mathrm{~Hz}, 1 \mathrm{H})$. 


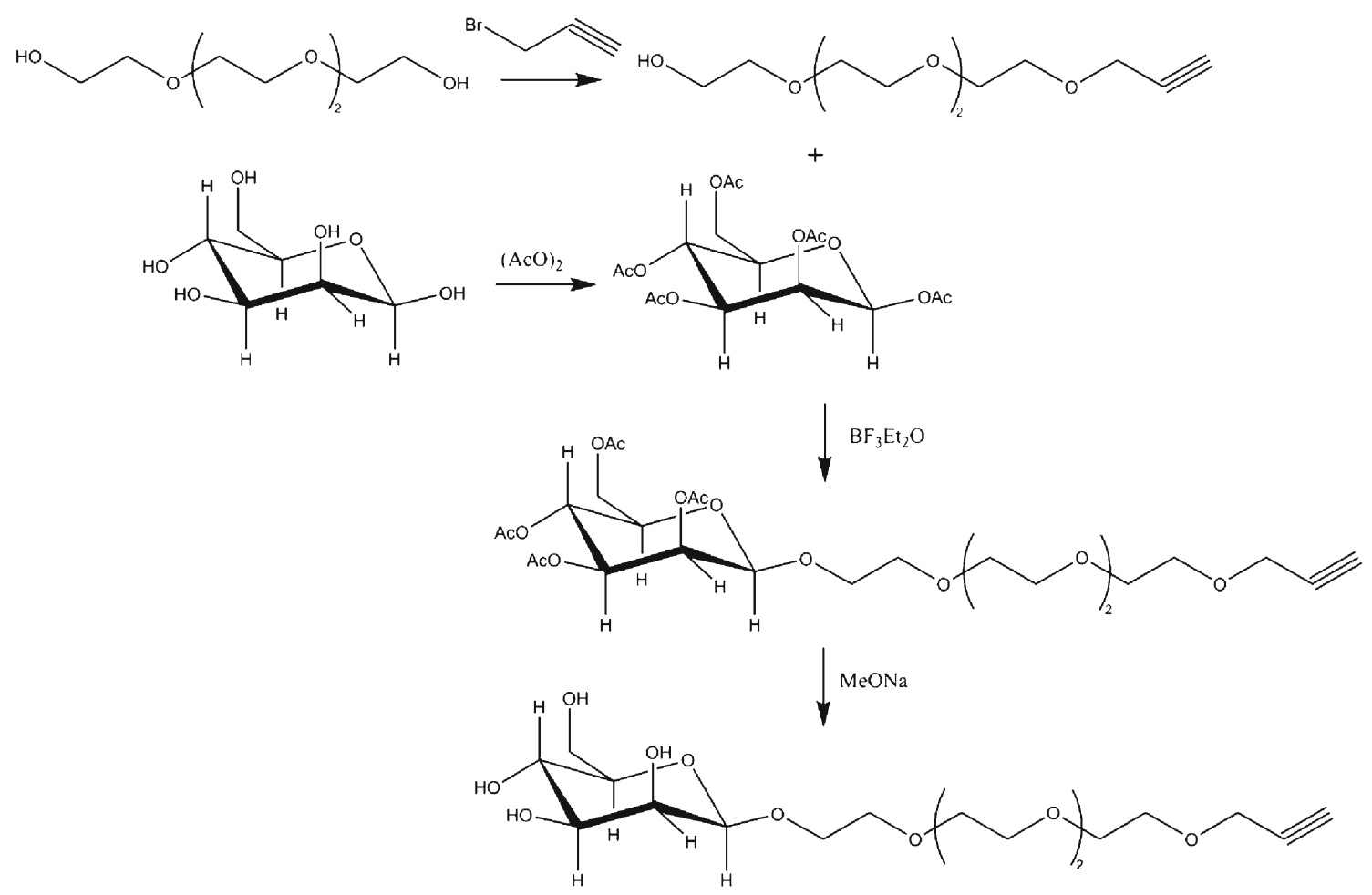

Fig. 1 Synthesis of the clickable D-mannose with TEG linker

Membrane preparation and modification

For the electrochemical experiments, parent membranes were prepared by dissolving $10 \mathrm{mmol} \mathrm{kg}{ }^{-1}$ of ionophore (valinomycin or KTClPB), $10 \mathrm{wt} \%$ of ETH $50030 \mathrm{wt} \%$ of $8 \% \mathrm{~N}_{3} \mathrm{PVC}$ and $60 \mathrm{wt} \%$ of DOS in THF, casting this solution into glass rings and evaporating the THF overnight. Membranes of $7 \mathrm{~mm}$ diameter were punched from the parent membrane and mounted in Ostec bodies. $1 \mathrm{mM} \mathrm{KCl}$ or $1 \mathrm{mM}$ of $\mathrm{TBACl}$ was used as the inner and conditioning solution.

For the potentiometric experiments, membrane compositions were as follows: $10 \mathrm{mmol} \mathrm{kg}{ }^{-1}$ of KTClPB, $30 \mathrm{wt} \%$ of $8 \% \mathrm{~N}_{3} \mathrm{PVC}$ and $60 \mathrm{wt} \%$ of DOS. $1 \mathrm{M}$ TBACl solution was used as the inner solution, membranes were conditioned overnight in $1 \mathrm{mM}$ phosphate buffer $(\mathrm{pH}=7.5)$ background.

The 'click' reaction mixture was prepared by dissolving $7.7 \mathrm{mg}(0.030 \mathrm{mmol})$ of $\mathrm{CuSO}_{4} \cdot 5 \mathrm{H}_{2} \mathrm{O}, 27.8 \mathrm{mg}(0.158 \mathrm{mmol})$

Table 1 Contact angle measurements

\begin{tabular}{ll}
\hline Surface & Contact angle/deg \\
\hline PVC & $80 \pm 1$ \\
Mannose modified PVC & $64 \pm 1$ \\
TEG modified PVC & $69 \pm 2$ \\
\hline
\end{tabular}

of ascorbic acid and $2 \mathrm{mg}(0.005 \mathrm{mmol})$ of clickable Dmannose in $1 \mathrm{~mL}$ of water. The membranes mounted in the Ostec body were subsequently immersed in the reaction mixture for $18 \mathrm{~h}$.

\section{Electrochemical measurements}

A previously reported [23] multi-pulse electrochemical (pulstrode) protocol was used in the measurements. The procedure consists of three pulses. The first pulse of $-9 \mu \mathrm{A}$ was applied for $0.5 \mathrm{~s}$ followed by a zero current pulse for another $0.5 \mathrm{~s}$ and finally a regeneration pulse was applied for $25 \mathrm{~s}$ at $0 \mathrm{~V}$. Potentials found at the end of the second pulse were used as data points. In chronopotentiometric experiments, a two pulse protocol was used: first $-5 \mu \mathrm{A}$ for $5 \mathrm{~s}$ and subsequently $50 \mathrm{~s}$ at the open circuit potential (OCP) measured before current perturbation. All chronopotentiometric measurements were performed in the presence of $10^{-4} \mathrm{M} \mathrm{KCl}$ or TBACl in a $1 \mathrm{mM}$ phosphate buffer $(\mathrm{pH}=7.5)$ background.

\section{Quartz crystal microbalance measurements}

Measurements were carried out using gold coated quartz crystals spin coated with $\mathrm{N}_{3} \mathrm{PVC}$ membranes and modified with TEG or D-mannose. Experiments were performed in a 
Fig. 2 Schematic representation of the sensing principle. As a biorecognition event takes place, current induced flux of ions across membrane - sample interface is disturbed by the buildup of a diffusion barrier, resulting in a decrease of ISE response
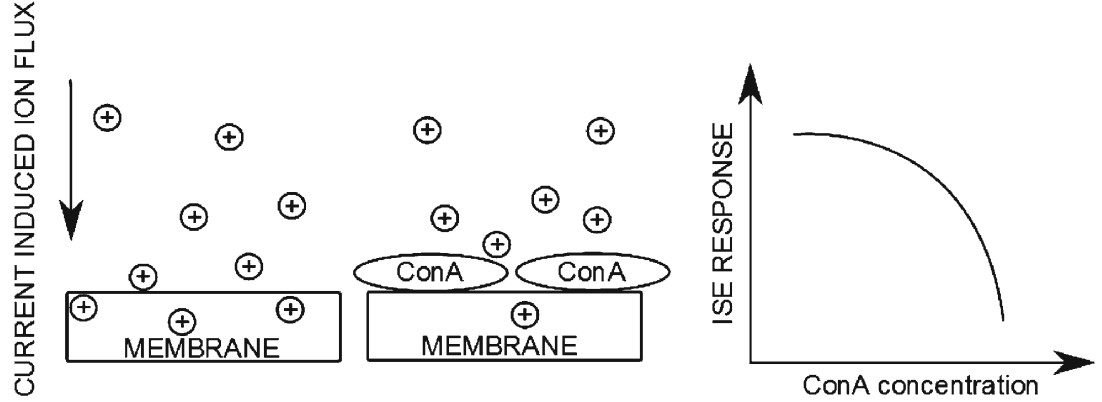

flow through cell with Concanavalin A in $1 \mathrm{mM}$ phosphate buffer solution $(\mathrm{pH}=7.5)$ pumped through the cell.

\section{Results and discussion}

Copper (I)-catalyzed Azide-Alkyne Cycloaddition (CuAAC, click chemistry) is a simple, yet very versatile tool to modify PVC, allowing also for immobilization of biomolecules such as biotin [22] or cysteine [30] on the surface of plasticized PVC membranes. In order to apply click chemistry in a membrane modification, azide groups have to be first introduced into the PVC backbone. A previously described procedure [32] was used to modify commercial high molecular weight PVC with $7 \%$ of azide groups. D-Mannose was modified on its anomeric carbon with tetraethylene glycol (TEG) bearing a propargyl group on one end, according to the reaction scheme presented in Fig. 1. Tetraethylene glycol was chosen as a linker to decrease nonspecific adsorption and to add some degree of mobility to the bound carbohydrate. Moreover, the anchoring linker at the anomeric position should not influence the interaction with Concanavalin A as it does not participate in the binding process [33]. Modified mannose was then immobilized on the surface of polymeric membrane, containing DOS as a plasticizer, lipophilic salt ETH 500 and potassium ionophore (valinomycin) or cation exchanger (depending on the electrochemical protocol).

As the surface properties of the materials influence the unspecific adsorption of proteins, the hydrophilicity of modified surfaces was investigated with contact angle measurements. Mannose modified membranes were compared with unmodified PVC and tetraethylene glycol modified ones. As shown in Table 1, the modification with mannose reduced the contact angle to 64 degrees, which is lower than that observed for TEG and unmodified PVC.

The mechanism of the sensor action is based on the disturbance of the current induced marker ion flux as a result of Concanavalin A binding to the mannose-modified sensor surface. The lectin binding disturbs the flux of the marker ion, creating a diffusional barrier in the vicinity of the sensor and resulting in a change of the membrane response. A schematic representation of the sensing principle is presented in Fig. 2.

Two membrane compositions were tested using the electrochemical protocols summarized in Table 2: one containing valinomycin (potassium ionophore) and a second one with cation exchanger (potassium tetrakis (4-chlorophenyl) borate) without ionophore to discriminate ions on the basis of their lipophilicity. In that case the rather lipophilic tetrabutylammonium cation was used as a marker ion. Calibrations of mannosemodified membranes of both compositions were performed using the current pulse protocol described below, with the corresponding marker ions and the point of highest sensitivity (i.e., middle point of the sigmoidal response curve) of the calibration curves was chosen as the marker ion concentrations for the Concanavalin A binding studies.

\section{Current pulse protocol}

First, potassium selective membranes were prepared and a current pulse protocol was used for the measurements. The protocol consisted of $0.5 \mathrm{~s}$ current pulse followed by $0.5 \mathrm{~s}$ zero current pulse at the end of which the potential was sampled.

Table 2 Summary of electrochemical protocols used

\begin{tabular}{lll}
\hline Method & Electrochemical protocol & Value used as analytical signal \\
\hline Current pulse protocol & $-9 \mu \mathrm{A}$ for $0.5 \mathrm{~s} 0 \mathrm{~A}$ for $0.5 \mathrm{~s}$ regeneration $25 \mathrm{~s}$ at $0 \mathrm{~V}$ & Potential value at the end of a zero current pulse \\
Chronopotentiometry & $-5 \mu \mathrm{A}$ for $5 \mathrm{~s}$ regeneration $50 \mathrm{~s}$ at the open circuit potential & Depletion time (inflection point on potential-time trace) \\
Passive flux method & Zero current conditions (potentiometry) & EMF change \\
\hline
\end{tabular}


Finally, $0 \mathrm{~V}$ regeneration potential was applied for $120 \mathrm{~s}$. As with biotynylated [23] and TEG [31] grafted surfaces, this methodology can reveal a diffusional barrier created by the protein bound at the membrane-sample interface. Concanavalin A calibration was performed in $1 \mathrm{mM}$ phosphate buffer at $\mathrm{pH} 7.5$ containing $10^{-5} \mathrm{M} \mathrm{Ca}^{2+}$, because mannose binding by lectin is calcium mediated [7], and at a constant potassium background of $10^{-4} \mathrm{M}$. It was found that $10 \mathrm{~min}$ is the minimum time required for the equilibration of the system and thus 15 min intervals were applied between addition of Concanavalin A and the measurement in all calibrations. As shown in Fig. 3, for concentrations of Concanavalin A above $10 \mu \mathrm{g} \mathrm{mL}^{-1}$, the membrane response to potassium starts to decrease because of an impeded transfer from the solution.

When valinomycin was substituted by a cation exchanger in the membrane and the lipophilic tetrabutylammonium cation was used as a marker ion instead of potassium, a significant increase of the response was observed (Fig. 3). The reason for this is likely linked to the excellent discrimination of the hydrophilic and dilute background by the tetrabutylammonium ion. Since the design of an ionexchanger based membrane is simpler and less expensive than an ionophore-based one, it is also likely preferred in practical applications.

To investigate nonspecific interactions, the mannosemodified electrode was treated with BSA (Fig. 3), but practically no response was observed. In a second control experiment, $\mathrm{N}_{3}$ PVC was modified with tetraethylene glycol according to the previously published procedure [31] because the contact angle measurement showed that TEG and mannose modified membranes exhibit similar hydrophilicity and

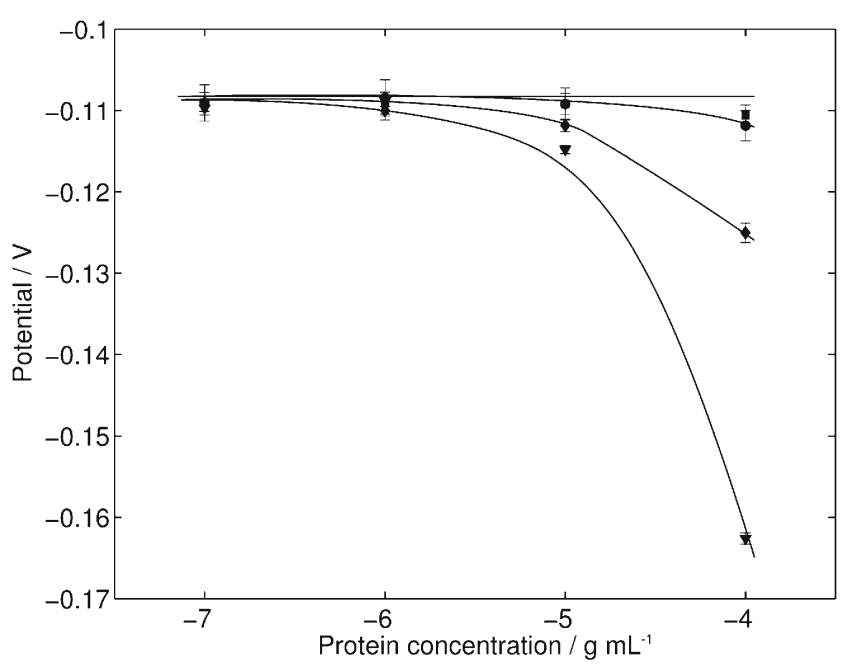

Fig. 3 Concanavalin A calibrations using short current pulse: for the potassium selective system (diamonds), tetrabutylammonium responsive membranes containing cation exchanger (triangles), BSA calibration of the membranes with cation exchanger (squares) and Concanavalin A calibration of membrane modified with TEG (circles) should result in comparable nonspecific protein adsorption on both surfaces. These TEG-modified electrodes were examined in the presence of Concanavalin A but almost no response was observed in this case as well (Fig. 3).

\section{Chronopotentiometry}

Chronopotentiometry is a powerful technique allowing one to examine ion depletion at the membrane-sample interface [34]. The chronopotentiometric protocol consists of 2 pulses: a long $(5 \mathrm{~s})$ current pulse followed by $50 \mathrm{~s}$ of regeneration at the open circuit potential determined before the current pulse. The current pulse results in the depletion of the measured ion at the membrane interface after a certain time (so-called transition time), which can be observed as an inflection of the potential-time trace. The transition time depends on the concentration of the analyte: lower concentrations require less time for ion depletion. In the studied system the protein layer formed at the surface caused a decrease in the observed transition time (Fig. 4). This can nominally be explained by a reduction of the available surface concentration by the protein mannose interaction, which results in a higher effective current density and hence to a faster depletion process.

Passive flux protocol

The response of mannose modified membranes to Concanavalin A in the presence of tetrabutylammonium was investigated in potentiometric detection mode as well, in analogy to other recent work [22]. To force a flux of ions across the sample-membrane interface under zero current conditions, a

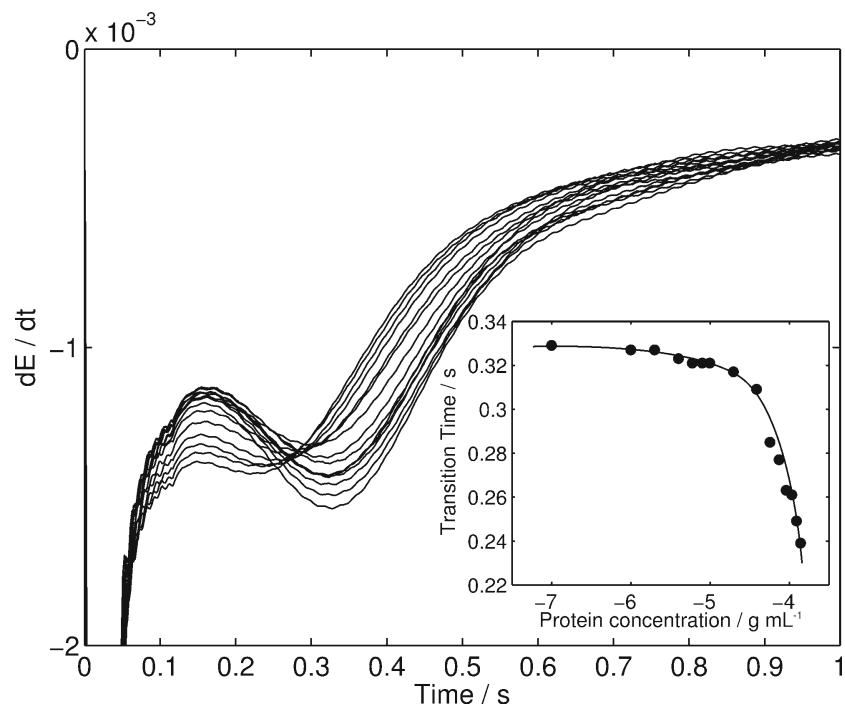

Fig. 4 Derivatives of chronopotentiometric traces obtained in Concanavalin A calibration with a membrane containing cation exchanger. Inset: calibration curve obtained from this data, transition time vs. Concanavalin A concentration 


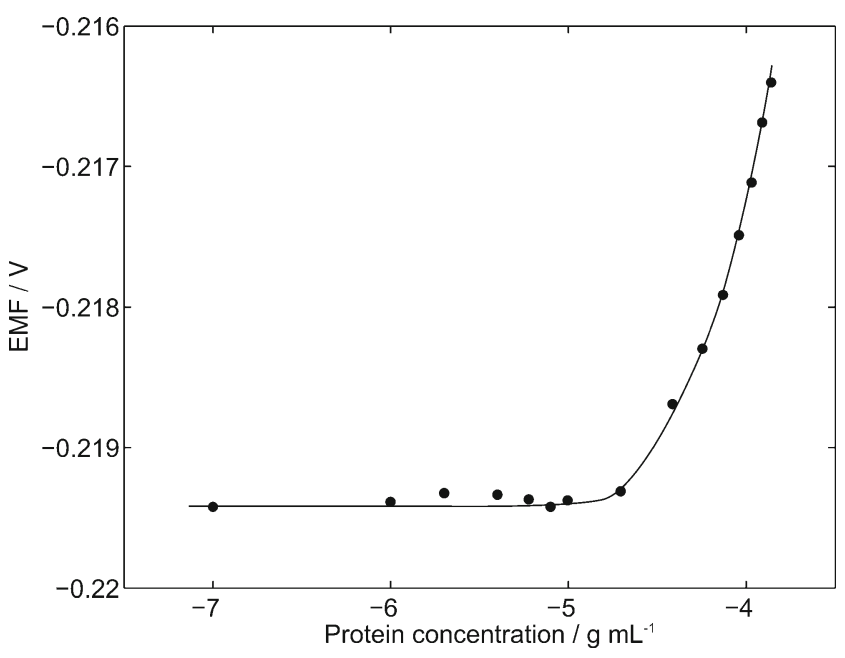

Fig. 5 Potentiometric calibration of Concanavalin A, membrane containing cation exchanger and $1 \mathrm{M}$ tetrabutylammonium in the inner solution

high concentration $(1 \mathrm{M})$ of tetrabutylammonium ions was used in the inner solution of the electrode, with only background electrolyte on the sample side. The high concentration gradient between inner filling and sample solution causes transport of the lipophilic marker ion across the membrane. When surface binding of protein takes place, the diffusion of the marker ion from the membrane surface to the bulk of the solution is restricted, resulting in an accumulation of ions, which, in turn, results in an increase of the membrane potential. To confirm the marker ion flux, a stirring experiment without Concanavalin A was first performed. When stirring was stopped, an increase of the signal resulting from ion accumulation was observed. The addition of protein had similar effect on the potentiometric response of the membranes (Fig. 5), although the response was only in the range of a few $\mathrm{mV}$, hence, much smaller than in the current pulse experiment.

Quartz crystal microbalance

Quartz crystal microbalance was used as a complementary technique to confirm the findings obtained with electrochemical methods. $\mathrm{N}_{3}$ PVC plasticized with DOS was spin coated on a fitting gold crystal and the resulting film was modified with mannose. This film was then treated with Concanavalin A (Fig. 6), resulting in a change in the observed crystal frequency by about $30 \mathrm{~Hz}$. Addition of EDTA to the sample mixture resulted in a removal of adsorbed protein from the surface caused by the competitive calcium complexation. A control experiment with the TEG-modified membrane showed that no adsorption of lectin takes place in the absence of carbohydrate.

Modified membrane — blood interactions

An interesting property of Concanavalin A is its capability of red blood cell agglutination through multivalent binding with carbohydrates present on the cell surface. Owing to the large blocking effect of bulky analytes, one should be able to detect entities as large as cells using the methodology presented here. Two membranes were modified with D-mannose, and one of them was incubated in a $1 \mathrm{mg} \mathrm{mL}^{-1}$ solution of Concanavalin A while the other one was kept in buffer only. Whole blood was added to a $\mathrm{pH} 7.4$ buffer solution containing tetrabutylammonium ions in increments from $10 \% \mathrm{v} / \mathrm{v}$ to $50 \%$ and the electrodes were investigated with the twocurrent-pulses protocol. As can be seen from Fig. 7, differences
Fig. 6 Results of quartz crystal microbalance experiments for Dmannose and TEG modified membranes treated with Concanavalin A
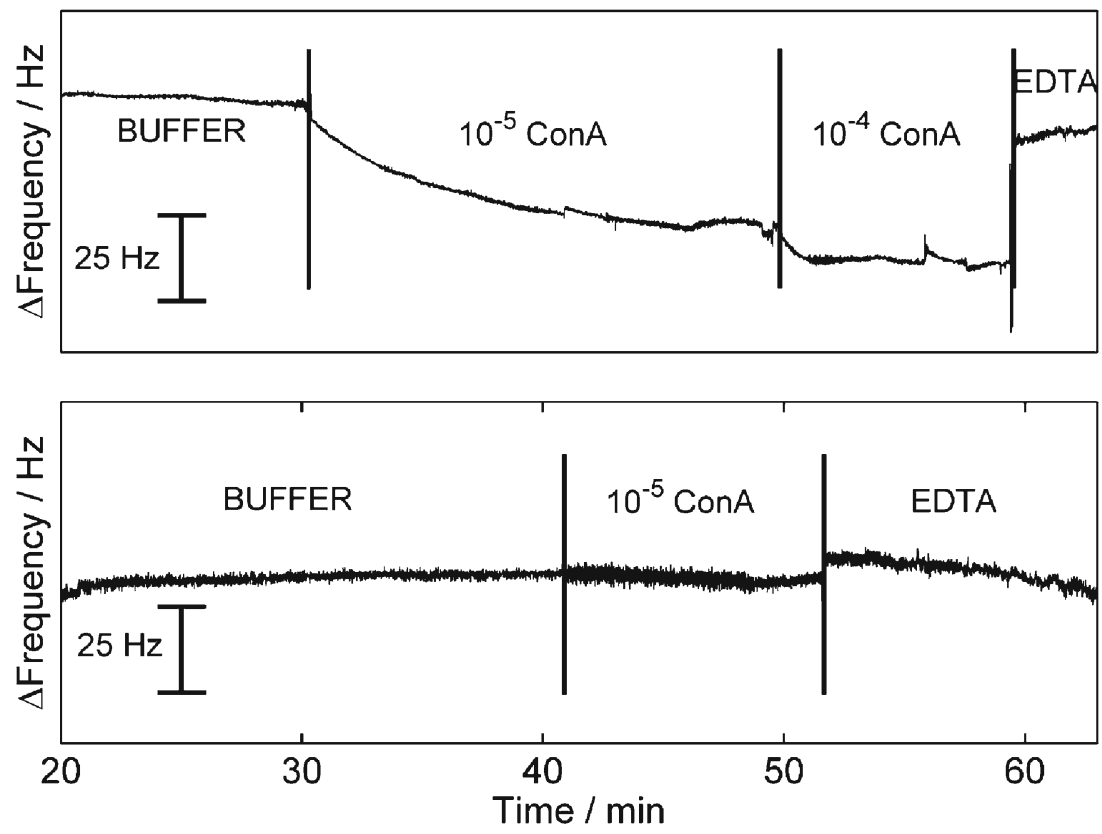
Fig. 7 Comparison of response of D-mannose modified membranes incubated in Concanavalin A (diamonds) and in buffer (squares) to increasing blood concentration (values on the $\mathrm{x}$-axis are volumetric blood:buffer ratios)

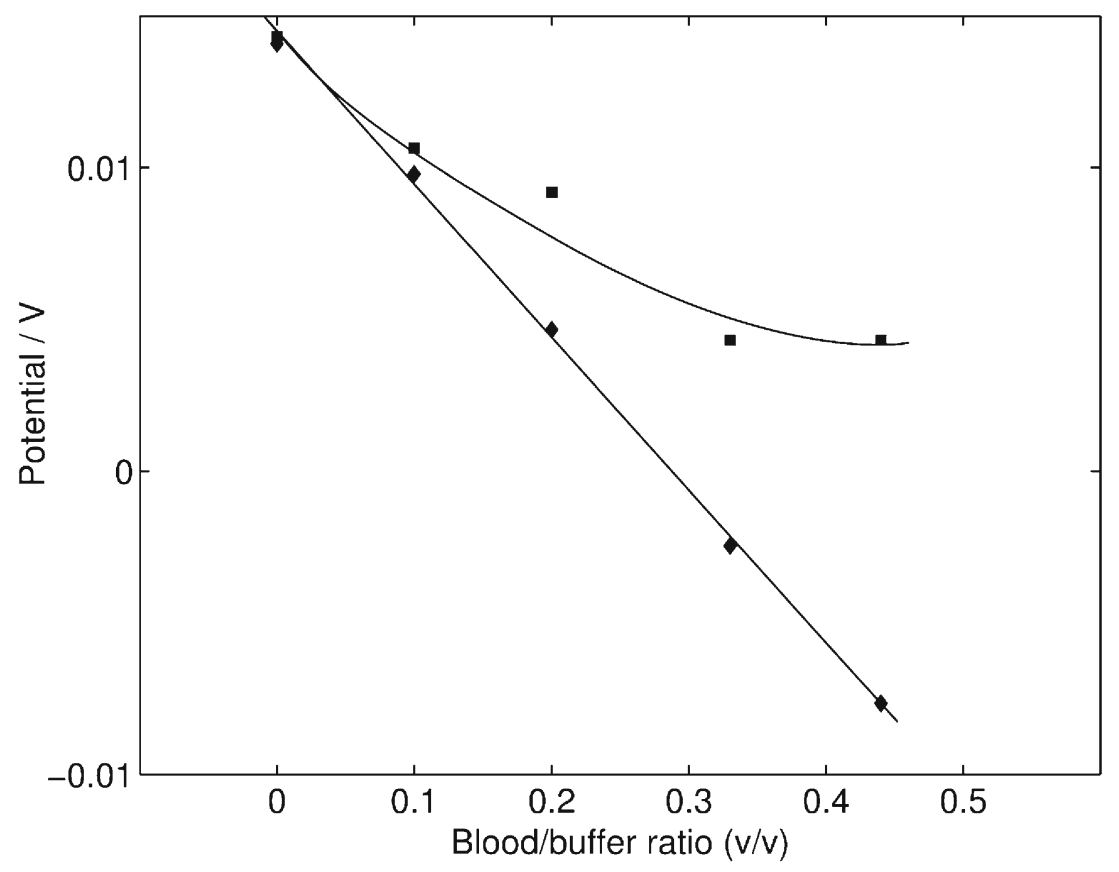

were observed between membranes incubated in Concanavalin $\mathrm{A}$ and in the buffer. These promising preliminary experiments may encourage further work in this direction.

\section{Conclusions}

A simple design of an electrochemical concanavalin A sensor with a limit of detection of $10 \mu \mathrm{g} \mathrm{mL}^{-1}$ was developed. The mechanism of Concanavalin A detection was confirmed with three different electrochemical protocols and by quartz crystal microbalance measurements. tetrabutylammonium-selective membranes were shown to generate higher signals than potassium selective ones. A pulstrode protocol consisting of two current pulses is also more sensitive than potentiometry or chronopotentiometry. Experiments with whole blood, although preliminary, suggest that this system could find application in cell-cell interaction studies, where carbohydrates immobilized on an ion selective membrane can form an

Table 3 Comparison of literature methods of Concanavalin A sensing

\begin{tabular}{|c|c|c|c|}
\hline Sensing principle & $\begin{array}{l}\mathrm{LOD} / \\
\mu \mathrm{M}\end{array}$ & Remarks & Ref \\
\hline Surface blocking with electrochemical detection & 0.1 & $\begin{array}{l}\text { Synthesis of clickable mannose and surface modification of ISE } \\
\text { membrane surface }\end{array}$ & This work \\
\hline \multirow[t]{3}{*}{ Surface plasmon resonance } & 0.01 & Multi step modification of gold chips & {$[8]$} \\
\hline & 20 & $\begin{array}{l}\text { Modification of gold surface with vapour deposition and nanosphere } \\
\text { lithography }\end{array}$ & {$[9]$} \\
\hline & 0.1 & $\begin{array}{l}\text { Gold substrate modified with SAM and carbohydrate immobilized } \\
\text { using click chemistry }\end{array}$ & {$[10]$} \\
\hline \multirow[t]{6}{*}{ Fluorescence spectroscopy } & 1 & Multi step synthesis of iridium complexes & {$[11]$} \\
\hline & 0.05 & Synthesis of terbium antenna complexes & {$[12]$} \\
\hline & 1 & Synthesis of mannose-substituted tetraphenylethenes & {$[13]$} \\
\hline & 1 & Synthesis of lectin-phosphole oxide conjugates & {$[14]$} \\
\hline & 0.01 & Synthesis of water-soluble conjugated glycopolymer & {$[15]$} \\
\hline & 4 & Synthesis of triazatruxene-based glycocluster & {$[16]$} \\
\hline \multirow[t]{2}{*}{ Voltammetry } & 10 & Synthesis of ferrocene-mannose conjugates & {$[17]$} \\
\hline & 5 & Synthesis of PAMAM based glycodendrimers with mannose-ferrocene units & {$[18]$} \\
\hline \multirow[t]{2}{*}{ Electrochemical impedance spectroscopy } & 0.02 & Gold nanostructuring of screen printed carbon electrodes & {$[19]$} \\
\hline & 50 & Addition of nonionic glycosylated surfactant to the membrane matrix & {$[20]$} \\
\hline
\end{tabular}


attractive mimic of the cell surface. A comparison with other methods of Concanavalin A detection found in the literature shows that the method in this work is one of the most sensitive and simple methods among all electroanalytical protocols (Table 3). Although some fluorescence spectroscopy or surface plasmon resonance techniques are shown to exhibit better limits of detection, they usually require more complicated synthetic routes and involve more complex and expensive equipment.

Acknowledgments The authors thank the Swiss National Science Foundation (FNS) for supporting this work. GM gratefully acknowledges the support of the Austrian Science Fund (FWF): J3343.

\section{References}

1. Lis H, Sharon N (1998) Lectins: carbohydrate-specific proteins that mediate cellular recognition. Chem Rev 98(2):637-674. doi:10. $1021 / \mathrm{cr} 940413 \mathrm{~g}$

2. McCoy JJ, Mann BJ, Petri WA (1994) Adherence and cytotoxicity of Entamoeba histolytica or how lectins let parasites stick around. Infect Immun 62(8):3045-3050

3. Ofek I, Sharon N (1990) Adhesins as lectins: specificity and role in infection. Curr Top Microbiol Immunol 151:91-113, Copyright (C) 2013 U.S. National Library of Medicine

4. Colnot C, Ripoche M-A, Fowlis D, Cannon V, Scaerou F, Cooper DNW, Poirier F (1997) The role of Galectins in mouse development. Trends Glycosci Glycotechnol 9(45):31-40

5. Sharon N, Lis H (1989) Lectins as cell recognition molecules. Science 246(4927):227-234. doi:10.1126/science.2552581

6. Kilpatrick DC, Green C (1992) Lectins as blood typing reagents. Adv Lectin Res 5:51-94, Copyright (C) 2013 American Chemical Society (ACS). All Rights Reserved

7. Bouckaert J, Loris R, Poortmans F, Wyns L (1995) Crystallographic structure of metal-free concanavalin A at $2.5 \AA$ resolution. Proteins 23(4):510-524. doi:10.1002/prot.340230406

8. Huang C-F, Yao G-H, Liang R-P, Qiu J-D (2013) Graphene oxide and dextran capped gold nanoparticles based surface plasmon resonance sensor for sensitive detection of concanavalin A. Biosens Bioelectron 50(0):305-310. doi:10.1016/j.bios. 2013.07.002

9. Yonzon CR, Jeoung E, Zou S, Schatz GC, Mrksich M, Van Duyne RP (2004) A comparative analysis of localized and propagating surface plasmon resonance sensors: the binding of concanavalin A to a monosaccharide functionalized self-assembled monolayer. J Am Chem Soc 126(39):12669-12676. doi:10.1021/ja047118q

10. Zhang Y, Luo S, Tang Y, Yu L, Hou K-Y, Cheng J-P, Zeng X, Wang PG (2006) Carbohydrate - protein interactions by "clicked" carbohydrate self-assembled monolayers. Anal Chem 78(6):2001-2008. doi:10.1021/ac051919+

11. Mandal S, Das R, Gupta P, Mukhopadhyay B (2012) Synthesis of a sugar-functionalized iridium complex and its application as a fluorescent lectin sensor. Tetrahedron Lett 53(30):3915-3918. doi:10. 1016/j.tetlet.2012.05.075

12. Martin Rodriguez E, Bogdan N, Capobianco JA, Orlandi S, Cavazzini M, Scalera C, Quici S (2013) A highly sensitive luminescent lectin sensor based on an $\alpha$-D-mannose substituted $\mathrm{Tb} 3+$ antenna complex. Dalton T 42(26):9453-9461. doi:10.1039/ c3dt33023k

13. Sanji T, Shiraishi K, Nakamura M, Tanaka M (2010) Fluorescence turn-On sensing of lectins with mannose-substituted tetraphenylethenes based on aggregation-induced emission. Chem-Asian J 5(4):817-824. doi:10.1002/asia.200900430

14. Sanji T, Shiraishi K, Tanaka M (2008) Sugar - phosphole oxide conjugates as "turn-on" luminescent sensors for lectins. ACS Appl Mater Interfaces 1(2):270-273. doi:10.1021/am800224r

15. Shi J, Cai L, Pu K-Y, Liu B (2010) Synthesis and characterization of water-soluble conjugated glycopolymer for fluorescent sensing of concanavalin A. Chem-Asian J 5(2):301-308. doi:10.1002/asia. 200900297

16. Wang K-R, Wang Y-Q, An H-W, Zhang J-C, Li X-L (2013) A triazatruxene-based glycocluster as a fluorescent sensor for concanavalin A. Chem-Eur J 19(8):2903-2909. doi:10.1002/chem. 201200905

17. Casas-Solvas JM, Ortiz-Salmeron E, Garcia-Fuentes L, VargasBerenguel A (2008) Ferrocene-mannose conjugates as electrochemical molecular sensors for concanavalin A lectin. Org Biomol Chem 6(22):4230-4235. doi:10.1039/b809542f

18. Martos-Maldonado MC, Casas-Solvas JM, Quesada-Soriano I, García-Fuentes L, Vargas-Berenguel A (2013) Poly (amido amine)based mannose-glycodendrimers as multielectron redox probes for improving lectin sensing. Langmuir 29(4):1318-1326. doi:10.1021/ la304107a

19. Loaiza OA, Lamas-Ardisana PJ, Jubete E, Ochoteco E, Loinaz I, Gn C, García I, Penadés S (2011) Nanostructured disposable Impedimetric sensors as tools for specific biomolecular interactions: sensitive recognition of concanavalin A. Anal Chem 83(8):29872995. doi:10.1021/ac103108m

20. Muslinkina L, Pretsch E (2004) Recognition of concanavalin A at the interface between a solvent polymeric membrane and an aqueous sample monitored by electric impedance spectroscopy. Chem Commun 10:1218-1219. doi:10.1039/b401864h

21. Gyurcsanyi RE, Vigassy T, Pretsch E (2003) Biorecognitionmodulated ion fluxes through functionalized gold nanotubules as a novel label-free biosensing approach. Chem Commun 20:25602561. doi:10.1039/b307393a

22. Ozdemir MS, Marczak M, Bohets H, Bonroy K, Roymans D, Stuyver L, Vanhoutte K, Pawlak M, Bakker E (2013) A labelfree potentiometric sensor principle for the detection of antibody-antigen interactions. Anal Chem 85(9):4770-4776. doi: $10.1021 / \mathrm{ac} 400514 \mathrm{u}$

23. Xu Y, Bakker E (2008) Ion channel mimetic chronopotentiometric polymeric membrane ion sensor for surface-confined protein detection. Langmuir 25(1):568-573. doi:10.1021/la802728p

24. Ghosh G, Bachas L, Anderson K (2007) Biosensor incorporating cell barrier architectures for detecting Staphylococcus aureus alpha toxin. Anal Bioanal Chem 387(2):567-574. doi:10.1007/s00216-0060949-5

25. Ghosh G, Bachas L, Anderson K (2008) Biosensor incorporating cell barrier architectures on ion selective electrodes for early screening of cancer. Anal Bioanal Chem 391(8):2783-2791. doi:10.1007/s00216008-2192-8

26. Ghosh G, Mehta I, Cornette AL, Anderson KW (2008) Measuring permeability with a whole cell-based biosensor as an alternate assay for angiogenesis: comparison with common in vitro assays. Biosens Bioelectron 23(7):1109-1116. doi:10.1016/j.bios.2007.10.023

27. May KML, Vogt A, Bachas LG, Anderson KW (2005) Vascular endothelial growth factor as a biomarker for the early detection of cancer using a whole cell-based biosensor. Anal Bioanal Chem 382(4):1010-1016. doi:10.1007/s00216-005-3224-2

28. May KML, Wang Y, Bachas LG, Anderson KW (2004) Development of a whole-cell-based biosensor for detecting histamine as a model toxin. Anal Chem 76(14):4156-4161. doi:10.1021/ ac049810+

29. Belegrinou S, Menon S, Dobrunz D, Meier W (2011) Solidsupported polymeric membranes. Soft Matter 7(6):2202-2210. doi: $10.1039 / \mathrm{C} 0 \mathrm{sm} 01163 \mathrm{k}$ 
30. Pawlak M, Grygolowicz-Pawlak E, Crespo GA, Mistlberger G, Bakker E (2013) PVC-based Ion-selective electrodes with enhanced biocompatibility by surface modification with "click" chemistry. Electroanal 25(8):1840-1846. doi:10.1002/ elan.201300212

31. Pawlak M, Mistlberger G, Bakker E (2012) In situ surface functionalization of plasticized poly (vinyl chloride) membranes by 'click chemistry'. J Mater Chem 22(25):12796-12801. doi:10.1039/ c2jm31118f

32. Pawlak M, Grygolowicz-Pawlak E, Bakker E (2010) Ferrocene bound poly (vinyl chloride) as ion to electron transducer in electrochemical Ion sensors. Anal Chem 82(16):6887-6894. doi:10. 1021/ac1010662

33. Loris R, Casset F, Bouckaert J, Pletinckx J, Dao-Thi M-H, Poortmans F, Imberty A, Perez S, Wyns L (1994) The monosaccharide binding site of lentil lectin: an X-ray and molecular modelling study. Glycoconj J 11(6):507-517. doi:10.1007/bf00731301

34. Ghahraman Afshar M, Crespo GA, Bakker E (2012) Direct Ion speciation analysis with ion-selective membranes operated in a sequential potentiometric/time resolved chronopotentiometric sensing mode. Anal Chem 84(20):8813-8821. doi:10.1021/ ac302092m 